\title{
Chronic hepatitis B virus infection and hepatocellular carcinoma in Sub-Saharan Black African children: the pre-vaccination era
}

\author{
M. Kew \\ Received: 18 February 2015; Accepted: 23 February 2015 \\ (C) Lavoisier SAS 2015
}

With the vaccination program against hepatitis $B$ virus (HBV) infection of new-born Black African babies not yet fully functional in sub-Saharan countries, we should remind ourselves of the frequency of chronic infection with this virus and its dire consequences, most notably the development of hepatocellular carcinoma (HCC), in the sub-Saharan Black population. Children are an early concern.

Although HBV-induced HCC in sub-Saharan Black Africans occurs most often in young or middle-aged adults, the tumour also occurs in children, albeit in fewer numbers: in $1 \%$ of children less than 6 months of age, and $13 \%$ of children over one year of age [1]. The latter are, with few exceptions, aged between 5 and 15 years, and have a male/female ratio of 2 or 3:1 [1]. In common with the majority of Black African adults with HCC, most of the children with the tumour are born and live in rural areas [1-5], with the ratio of rural-born to urban-born being 4.8:1 [5]. The characteristics of HCC in children do not differ significantly from those in adults, with the possible exception of a higher incidence of an hepatic arterial bruit (66\% cf 23\%) [1].

The aetiology of HCC in Black African children has generally been less extensively investigated than that in adults, but those studied have shown that chronic HBV infection is the almost invariable cause of the tumour [1]. In parallel with the incidence of HCC, the presence of the virus in rural areas is appreciably greater than in urban areas: for example, Black males in the Johannesburg region have an incidence of only $1.5 \%$ and females of only $0.57 \%$ [5]. In an early study of Black African children with HCC, HBV surface antigen and antibody against the core antigen were present in the serum of all of the children, with antibody to hepatitis $\mathrm{Be}$ antigen being present in two-thirds [1]. These findings suggest the possibility that nearly all, or perhaps even all, Black African children with HCC are chronically infected

\footnotetext{
M. Kew $(\square)$

Department of Medicine,

University of Cape Town and Groote Schuur Hospital,

Cape Town, South Africa

e-mail : michael.kew@uct.ac.za
}

with $\mathrm{HBV}$ at an early age and that the virus plays the same, if not a greater, role in causing HCC in children than it does in adults. Based on the ages of the published children with HBV-induced HCC, it seems likely that tumour formation may occur within 10 to 15 years of the initial infection. In the majority of Black children with HCC, cirrhosis is present in the non-tumorous liver.

Evidence from sub-Saharan Africa and the Far East indicates that the route of acquisition of HBV in children is mainly 'horizontal' rather than 'vertical'. An interval of approximately 10 years between HBV infection and the occurrence of HCC represents the usual time between exposure to the virus and the appearance of the tumour, although time spans may be as short as 6 years. The fact that the majority of Black children (and adults) with HCC live in a rural environment is attributed to the fact that the carcinogens exist in a rural to a significantly greater extent than in an urban environment. Black adults who leave the countryside to work in the cities develop the tumour at an older age (48 years) than those who remain in a rural environment (35 years) [1].

A likely co-carcinogen to HBV in the rural environment is dietary exposure to the fungal hepatocarcinogen, aflatoxin $\mathrm{B}_{1}$, and we should bear in mind that exposure to this agent remains an important cause of HCC in rural regions of subSaharan Africa, irrespective of what happens to HBV.

\section{References}

1. Botha JF, Ritchie MJJ, Dusheiko GM, et al (1984) Hepatitis B carrier state in Black children in Ovamboland. Role of perinatal and horizontal infection. Br Med J 2: 1209-12

2. Williams AO, Edgington GM, Obakponovwe PC (1967) Hepatocellular carcinoma in infancy and childhood in Ibadan, Western Nigeria. Br J Cancer 21: 474-82

3. Cameron HM, Warwick GP (1977) Primary cancer of the liver in Kenyan children. Br J Cancer 36: 793-803

4. Akinyinka OO, Falade AG, Ogunbiyi O, Johnson AO (2001) Hepatocellular carcinoma in Nigerian children. Ann Trop Paediatr 21: 169-74

5. Kew MC, Kassianides K, Hodkinson J, et al (1986) Hepatocellular carcinoma in urban Blacks. Ferquency and relation to hepatitis B virus infection. Br Med J (Clin Res Ed) 293: 1339-41 